\title{
Accounting for Waqf Institutions: Business, Not-for-Profit or Hybrid Entities?
}

\author{
Umar Habibu Umar \\ Universiti Brunei Darussalam, Brunie Darussalam \\ Corresponding email: uhumar21@gmail.com \\ Md Harashid Haron \\ School of Management, Universiti Sains Malaysia, Malaysia
}

Article History

Received: May 8th, $2021 \quad$ Revised: July 9th, $2021 \quad$ Accepted: July 28th, 2021

\begin{abstract}
Despite the tremendous religious and socio-economic contributions of waqf institutions to Muslim communities across the globe, there was no universal accounting standard to adopt by such institutions until 15 Rabi'll (equivalent to $30^{\text {th }}$ November 2020) when the Accounting Standard for waqf institutions (FAS No. 37) was approved by the Board of Accounting and Auditing Organization for Islamic Financial Institutions (AAOIFI) for adoption with effect from 01 January, 2022. Hence, the objective of this study is to analyze the nature of waqf institutions with a view to establishing whether their appropriate financial accounting and reporting practices should be for business, not-for-profit or both. The documentary research method was applied to achieve the aim of this study through a systematic analysis of relevant accounting and Shariáh standards. Findings and views of earlier studies were also used. The study reveals that though waqf institutions operate like charitable organizations, they are mandated to undertake or attach to commercial activities in order to generate income for the sustainability of their activities. This signified that they are hybrid and as such, they are supposed to report both waqf and commercial activities in their annual reports and accounts. Hence, the study calls on Islamic countries to provide regulations, guidelines and more importantly accounting standards that will compel or motivate waqf institutions to prepare annual reports and accounts showing both their charitable and commercial activities.
\end{abstract}

Keywords: Waqf, Waqf Institutions, Waqf Accounting, AAOIFI

JEL Classification: M41, I31

Type of Paper: Research Paper

@ IJIEF 2021 published by Universitas Muhammadiyah Yogyakarta, Indonesia All rights reserved

DOI:

Web:

https://doi.org/10.18196/ijief.v4i2.11734 https://journal.umy.ac.id/index.php/ijief/article/view/11734

Citation:

Umar, U. H. \& Haron, M. H. (2021). Accounting for waqf Institutions: Business, not-for-profit or hybrid entities?. International Journal of Islamic Economics and Finance (IJIEF), 4(2), 293-314. DOI: https://doi.org/10.18196/ijief.v4i2.11734 
Umar \& Haron | Accounting for Waqf Institutions: Business, Not-for-Profit or Hybrid Entities?

\section{Introduction}

\subsection{Background}

Waqf (pl. awqaf) is an unincorporated trust established under the Shari'ah by a living man /woman in order to provide designated social services in perpetuity (Kuran, 2001). It is an Islamic endowment, which has been a common practice in Muslim society right from the time of the Prophet (peace be upon him) (Yaacob and Nahar, 2017). Nowadays, the idea of waqf is popular and practiced across the globe and North America and operates under the name of foundations (Kahf, n.d). The name "foundation" has been extended to the rest of the world. Waqf has gained the special attention and interest of the Muslim community because of the critical role it plays in the provision of a wide range of public goods (Mahata, Jaaffara and Abdul Rasoola, 2015; Yaacob, Petra, Sumardi and Nahar, 2015). During the period of the Ottoman Empire, waqf institutions contributed significantly to the provision of social amenities in Muslim countries free of charge in various forms, such as education, healthcare and other social amenities for a lot of Muslim countries (Zarqa, 1994; Miran, 2009; Yaacob et al., 2015; Yaacob and Nahar, 2017). Therefore, the significance of waqf institutions is very profound, as they perform an essential role in taking care of the needs of the family and society members at large (Umar, 2019).

In recent years, many efforts to revitalize waqf institutions were witnessed for a better and just society (Ihsan, Sulaiman, Alwi and Adnan, 2017). For example, in 2017 the Islamic Development Bank through its research wing, the Islamic Research and Training Institute (IRTI), Jeddah, collaborated with the Islami Bank Bangladesh and the Center for Zakat Management, Bangladesh and organized an international research workshop, entitled "Revival of Waqffor Socio-economic Development". This workshop took place in Dhaka, Bangladesh, from 4-5 November, 2017 and provided an avenue for scholars and practitioners from eleven (11) countries, including Bangladesh, Brunei, Indonesia, Japan, Kingdom of Saudi Arabia, Malaysia, New Zealand, Nigeria, Thailand, the United Kingdom and the United States of America, who presented well-researched papers on the various aspects of waqf towards its revival for socio-economic development.

The revitalization of waqf institutions justified the need for the establishment of a good accounting system for them (Ihsan and Adnan, n.d.; Masruki and Shafii, 2013; Talib, Latiff, Aman and Palil, 2018). Perhaps, prior to the last decade academics had paid little attention to waqf accounting (Ihsan and Adnan, n.d.). Extant review of awqaf literature in Malaysia reveals poor accountability of waqf properties for some reasons, such as incompetent personnel and inadequate resources to maintain and develop waqf assets as well as the mismanagement and misappropriation of waqf funds (Yaacob, 
Umar \& Haron | Accounting for Waqf Institutions: Business, Not-for-Profit or Hybrid Entities?

Petra, Sumardi and Nahar (2012). Besides, the institutions' financial accounting and reporting practices are diverse (Masruki and Shafii, 2013; Azmi and Hanifa, 2015; Yaacob et al., 2015; Talib et al., 2018).

Many waqf institutions exist in Islamic countries mostly in the form of foundations. Lack of waqf accounting standards contributed to the poor accountability and transparency in these institutions and consequently jeopardized their sustainability. Moreover, attributing commercial undertakings to waqf institutions creates confusion as to whether their accounts should be prepared as public or private entities. Some suggest adapting the accounting framework of for-profit entities (like Azmi and Hanifa, 2015) while others are of the view of applying that of not-for-profit entities (like Hamdan, Ramli, Jalil and Haris, 2013). Previous studies have failed to clearly establish a unanimous view on what waqf institutions should present in their annual reports and accounts.

In order to mitigate the impact of the COVID-19 pandemic on the Ummah, waqf is one of the Islamic social finance instruments that have been found viable (Umar, 2021). Several calls were made for special publications on the role of Islamic finance during the COVID-19 and beyond in both Islamic and conventional journals as well as book chapters, such as the International Journal of Islamic and Middle Eastern Finance and Management, Eurasian Economic Review, Jurnal Ekonomi Malaysia, International Journal of Zakat, Journal of Islamic Monetary Economics and Finance, Journal of Economic and Administrative Sciences, European Journal of Islamic Finance and COVID-19 and Islamic Social Finance (edited books), among others, with a view to soliciting expert views on various ways of applying waqf to enhance the socioeconomic development of the ummah. However, a survey made in the already published papers/chapters and recent call notifications have shown that accounting and reporting practices for waqf institutions have not been discussed though these institutions have been established to alleviate poverty and enhance socio-economic development during the COVID-19 and beyond. Hence, this study believes that waqf institutions would not achieve their objectives efficiently and effectively during the pandemic and beyond without proper accounting and reporting practices. Lack of proper accountability and transparency through the preparation of relevant annual reports and accounts could easily lead to the collapse of waqf institutions irrespective of the value of the assets contributed to them. Hence, this study is expected to contribute to the provision of how and what should be prepared and disclosed in such institutions annual reports and accounts.

Currently, there is only one waqf accounting standard issued by AAOIFI. This standard was approved on 15 Rabi'II, 1442 A.H (equivalent to $30^{\text {th }}$ November, 2020) and is expected to be adopted after 01 January 2022. At this juncture, 
Umar \& Haron | Accounting for Waqf Institutions: Business, Not-for-Profit or Hybrid Entities?

it is important to note that in most OIC member countries the adoption of AAOIFI's standards is not compulsory. This study analyzes the provisions of this standard with a view to suggesting additional financial statements not provided in the waqf accounting standard but are important to be prepared and disclosed in their annual reports and accounts.

\subsection{Objectives}

This study has three objectives:

1. To establish the nature of the waqf institution, whether profit, not for profit or hybrid.

2. To analyze the financial statements required to be prepared by waqf institutions with effect from $1^{\text {st }}$ January, 2022 as contained in the waqf accounting standard (FAS No. 37) developed by the AAOIFI.

3. To suggest additional financial statements to be prepared by waqf institutions in order to enhance accountability and transparency responsibilities in such institutions.

The remainder of this paper is organized into four Sections. Section 2 accommodates the literature review. Section 3 explains the methodology used. Findings and discussion are provided in section 4. Finally, Section 5 shows a conclusion and recommendations.

\section{Literature Review}

In this section, previous studies related to the waqf were reviewed. The fact is that there is no universal accounting standard specially developed for waqf institutions until when the Accounting and Auditing Organisation for Islamic Financial Institutions (AAOIFI) issued a waqf accounting standard, which is expected to be adopted effectively from 2022. This signifies that prior to 2022 no universal waqf accounting standard had existed to be complied with by waqf institutions. Consequently, the lack of clear guidelines or accounting standards for waqf institutions attracted the attention of a few researchers who proposed accounting for waqf institutions to ensure accountability and transparency in the institutions (Talib et al., 2018). Some studies discovered the non-uniformity of accounting practices by waqf institutions (such as Ihsan and Hameed, 2011; Yaacob et al., 2012; Talib et al., 2018; Azmi and Hanifa, 2015; Ihsan et al., 2017; Yaacob and Nahar, 2017). For example, Yaacob et al. (2012) examined the awqaf accounting and reporting practices of Awqaf $S$. It was found that the accounting and reporting of Awqaf $S$ were regulated by several acts and the annual financial statements prepared by the institutions. Azmi and Hanifa (2015) assessed whether the financial reporting practices of 
Umar \& Haron | Accounting for Waqf Institutions: Business, Not-for-Profit or Hybrid Entities?

waqf institutions conformed to AAOIFI's Sharia Standard No. 33 (SS 33) on waqf. The study revealed that though the institutions applied different accounting procedures and practices they conformed to the provisions of SS 33. However, AAOIFI's Sharia Standard No. 33 (SS 33) is not an accounting standard but the Shariáh. Therefore, compliance with it does not mean accounting compliance. Similarly, Yaacob et al. (2015) applied semistructured interviews and archival documentation review and analyses to assess the awqaf financial reporting and management of waqf-S. The study found the financial reporting and management of waqf-S very admirable, as its annual reports and accounts are published online on time.

Similarly, Talib et al. (2018) discovered that waqf accounting and reporting practices across the Malaysian States are diverse in terms of their guidelines, recognitions, measurements (valuation of waqf assets) and disclosure because each State Islamic Religious Councils (SIRC) is independent in discharging its constitutional duties. Ihsan and Hameed (2011) assessed the accounting practices of two selected named $A B C$ and $X Y Z$ in Indonesia through interviews, documentary evidence and direct observations. The findings showed that XYZ provided better accounting information and has more qualified employees than $A B C$. In addition, weaknesses in the accounting, reporting and investment of the waqf activities, more especially on waqf properties, were also found in Malaysia (Yaacob and Nahar, 2017).

Variations in waqf institution annual reports and accounts were noticed even in Malaysia despite being among the prime movers of the contemporary waqf practices in the Muslim world. This is because each Malaysian state has a State Islamic Religious Council (SIRC), a government agency that is saddled with the responsibility of developing legislations and procedures for the administration of waqf assets (Mansor, Jamil and Bahari, 2017). This signifies that SIRCs are independent in discharging their constitutional responsibilities, including issuing guidelines for waqf accounting and reporting practices in their respective states. Talib et al. (2018) examined the accounting and reporting practices of waqf institutions in eleven Malaysian states. The study found the waqf accounting and reporting practices across states diverse because each state has its own independent SIRC headed by the Sultan (the ruler) with his board members, who regulate the activities of waqf practices in the state.

Moreover, Talib et al. (2020) sought to explore the understanding of the effects of institutional pressures on the intention to apply accounting and reporting by waqf institutions in Malaysia. The data were generated through semi-structured interviews and documentary reviews. One of the key findings indicated that the challenges faced in adopting waqf accounting and reporting are attributed to coercive pressure like government regulations. Besides, normative pressures became key factors hindering the standardization of 
Umar \& Haron | Accounting for Waqf Institutions: Business, Not-for-Profit or Hybrid Entities?

waqf accounting and reporting. Also, mimetic pressure made it difficult to compare waqf accounting and reporting practices among the Malaysian State Islamic Religious Councils. Yusof (2021) used semi-structured interviews and document analysis methods to explore the need to have a specific accounting standard for waqf institutions. The study indicated how waqf institutions tried their best to comply with the prevailing standards that were specifically developed for them. It also showed the importance of issuing a specific accounting standard to be adopted by waqf institutions.

Briefly, based on the reviewed previous studies it is notable that the accounting and reporting practices of waqf institutions were not uniform, as they were prepared in various ways (Habidin, Hussin, Muhammad, Janudin and Fuzi, 2017). This is because the institutions were found to have no uniform waqf accounting standard to adopt in the preparation of their financial statements. This has made the annual reports and accounts of waqf institutions across the globe unworthy of comparability. In other words, it becomes very difficult to compare the financial accounting and reporting practices of waqf institutions, particularly in different countries, as there is no standard basis. The quality of waqf accounting information might also be compromised because of the application of different accounting and reporting practices by waqf institutions (Mansor et al., 2017). Another observed limitation of the previous studies is that they are mostly on an interview method, which is not believed to be a better in assessing the accounting and reporting practices of waqf institutions. The best way to assess the financial accounting and reporting practices is to look directly into the contents of their annual reports and accounts. Another limitation of using the interview method is the limitation of sample size. It is observable that most of these studies covered only one or two waqf institutions. Moreover, these studies failed to clearly show whether waqf institutions should be classified as business, nonprofit or hybrid entities with a view to establishing what should be prepared and presented in their annual reports and accounts.

The current study does not intend to assess the accounting and reporting practices of any waqf institution but rather provide a basic comprehensive package for the preparations of the financial statements of waqf institutions. It is expected to contribute toward enriching the contents of their annual reports and accounts with the relevant and needed financial information. Consequently, their performance could be assessed and compared. 
Umar \& Haron | Accounting for Waqf Institutions: Business, Not-for-Profit or Hybrid Entities?

\section{Methodology}

As earlier indicated, the aim of this study is to establish the appropriate class of waqf institutions in order to suggest what appropriate accounting information should be disclosed in the annual reports and accounts of such institutions. Hence, to achieve this objective documentary research method was applied as adapted from earlier studies like Umar, AbuBakar, Baita, Kademi and Haron (2021), who explored the contributions of academic and professional institutions to the promotion of awareness and knowledge of Islamic Banking and Finance in Nigeria. Documentary analyses entails a systematic procedure for reviewing or evaluating documents, both printed and electronic materials, and are obtainable in libraries, newspaper archives, historical society offices and organizational or institutional files (Bowen, 2009). This research method is frequently referred to as content analysis. According to Ahmed (2010), this method is widely used in all disciplines like anthropology, communications, economics, education, medicine, political science, social work and sociology. Thus, this study intends to systematically analyze relevant accounting and Shariáh standards, such as AAOFI's Waqf Accounting Standard (FAS No. 37), AAOIFI's Mushārakah Standard (FAS No. 4) and Bank Negara Malaysia Mushārakah Standard. The views and findings of previous relevant studies were also utilized.

Further, these documents were subjected to quality control tests, such as authenticity (genuineness and of unquestionable origin of the document), credibility (evidence-free from error and distortion of the evidence), representativeness (whether the studied documents could serve as a representative of the entirety of the relevant documents) and meaning (clarity and comprehensibility of the evidence) suggested by Scott (1990). The documents used were found to have satisfied these requirements, as they are officially published by reputable government agencies and professional associations, such as the Bank Negara Malaysia and the Accounting and Auditing Organization for Islamic Financial Institutions.

\section{Result and Analysis}

\subsection{The Nature of Waqf Institutions}

Basically, institutions could be broadly divided into two classes: public and private. Public institutions primarily provide essential goods and services to the public or members of the society whereas the major objective of private institutions is to maximize the wealth of shareholders. Hence, government ministries, departments, agencies and parastatals as well as nongovernmental organizations (NGOs) are considered as public institutions, as they primarily exist for the welfare and socio-economic development of 
Umar \& Haron | Accounting for Waqf Institutions: Business, Not-for-Profit or Hybrid Entities?

society members. On the other hand, companies, partnership businesses and one-man businesses are private institutions, whose major objective is to make a profit.

According to Kahf (2012), a waqf institution does not connote a legal entity on its own, but it is seen as a legal institution. Waqf institutions are synonymous with charitable bodies and in the eyes of the Shariáh they are created for charitable, pious and religious purposes (Yaacob et al., 2012). Therefore, waqf institutions are like philanthropic entities, which are also called not-for-profit organizations (NGOs) (Kamaruddin and Ramlia, 2015). The essential features of a not-for-profit organization, according to the United Nations include an organizational structure, not-for-profit motive, institutionally separate from government, self-governing and non-compulsory (Yaacob et al., 2012). These features are almost attributed to waqf institutions.

Today, many charitable organizations, commonly known as foundations, exist in both Muslim and non-Muslim countries across the globe. Almost every renowned successful entrepreneur in the world has established his/her foundation through which he/she carries out philanthropic activities, particularly in the areas of education, healthcare and poverty alleviation programs. For example, in the Muslim world, the contribution of Sulaiman bin Abdul Aziz Al Rajhi, a Saudi Arabian businessman, would never be forgotten. Al Rajhi dedicated his $19.7 \%$ shareholdings at one of the largest Islamic banks in the world as waqf. Therefore, all dividends and other benefits attributed to such shareholdings are solely used for discharging religious and philanthropic activities through Sulaiman bin Abdul Aziz Al Rajhi Endowments Holding Company (Umar, 2021). Similarly, Bill Gates together with his wife established the Bill and Melinda Gates Foundation, Azim Premji has Azim Premji Foundation, etc. Hence, waqf institutions are charitable or non-governmental organizations (NGOs), as they are not primarily established as profit-oriented organizations, but the provisions of social amenities are their core objective.

Waqf institutions are mandated to continue to exist forever based on one of their essential features, known as perpetuity. Perpetuity enables the waqf property to continue to exist continuously for the intended purpose without being lost or sold. It has a perpetual existence if it continues to provide endless assistance to beneficiaries even when the endower is dead (Yalawae and Tahir, 2008). This is possible if the waqf property is used to generate a profit or a sustainable source of income is attached to it. Hence, waqf involves the process of relocating an asset from the depletion to the appreciation side for the sustainable welfare of the intended users (Umar, 2019).

Moreover, Kahf (2003) states that the formation of a waqf institution is similar to that of a business entity that is expected to remain perpetual in order to 
Umar \& Haron | Accounting for Waqf Institutions: Business, Not-for-Profit or Hybrid Entities?

generate income for the welfare of future generations. Similarly, the waqf institution would not perpetually exist if the confined assets don't generate revenue continually (Umar, 2019). In other words, waqf properties themselves cannot give sustainable benefits to the intended beneficiaries unless they are used to undertake commercial operations (Salarzehi, Armesh and Nikbin, 2010). This shows the presence of the element of business undertakings in waqf institutions for their sustainability. A good example of modern waqf that is fully integrated with various going concern businesses is the one made by Sulaiman Bin Abdulaziz AlRajhi. AlRajhi waqf has three major investment centers, such as financial and real estate investment, food and agricultural investment and industrial investment that continuously provide income to execute the waqf activities (Umar, 2021).

However, since the key objective of waqf is to improve the welfare of the Ummah, it is recommended that the social enterprise waqf fund model (SEWF) should be applied by the institutions in carrying out their business, so that the gap could be bridged between the business and benevolence (Shulthoni and Saad, 2018). In other words, adopting the social enterprise waqf fund model (SEWF) would enable the waqf institutions to earn reasonable profits by selling their products to the public at fair and affordable prices.

Briefly, based on the above discussion and in the view of the authors, waqf institutions are hybrid entities, as they have both philanthropic and business entity features. But we believe that philanthropic activities dominate commercial activities, as they are primary and secondary raison d'etre, respectively.

\subsection{The Accounting for Waqf Properties/Assets}

Waqf entails the dedication of properties for the benefit of intended beneficiaries perpetually. They should neither be sold nor inherited (Osman, 2012). These properties may be providing services to the ummah (like schools that provide free education to needy students) or earn incomes (e.g. a shopping center declared as waqf by its owner, so that its rental income would be used to maintain the school) (Zarqa, 1994). There are two types of waqf assets: immovable assets and movable assets (Ibrahim and Ibrahim, n.d.). Under normal circumstances, waqf is attributed to non-perishable assets, so that their benefits and usufruct would be enjoyed by the beneficiaries without consuming the property itself (Talib et al., 2018). Specifically, real estate (like land) is the most suitable asset for waqf (Zarqa, 1994; Kahf, 2003; Abdullah and Ismail, 2015). This is because it is less likely be prone to misappropriation and embezzlement (Zarqa, 1994). Besides, they are durable assets that have a long lifespan. 
Umar \& Haron | Accounting for Waqf Institutions: Business, Not-for-Profit or Hybrid Entities?

However, some Muslim jurists permit the use of movable property as waqf assets, if there are valid texts or sound reasoning, for instance, horses are permitted to be used as waqf assets by a sound hadith and the use of trees and buildings are allowed by the Hanafi and Shafi'i Schools because they are annexed to land (Abdullah and Ismail, 2015). Similarly, Imam Shafi'i, Imam Malik and Imam ibn Habali permited the use of any movable property provided that it satisfies the requirement of perpetuity (Ibrahim and Ibrahim, n.d.).

In addition, in the fifteenth and sixteenth centuries, that is, during the Ottoman period, cash waqf was initiated for catering social and pious needs (Sait and Lim, 2006). Cash waqf entails the collection of money or funds for investment, so that the returns would be used to cover operating costs and distribute the excess (if any) among the beneficiaries in accordance with the waqf deeds (Yaacob et al., 2012). In order to validate the validity of cash waqf, Rusydiana and Devi (2018) stated the following:

[...] Imam Bukhari states that Ibnu Syihaab Az-Zuhri allows dinar and dirham waqf by making that dinar and dirham as business capital and distributing the profit for waqf (p. 2).

Also, the fatwa released by the World Fiqh Council (Majma' al-Fiqh) in Muscat, Sultanate of Oman, 6-11 March, 2004, validated the creation of cash Waqf for investment in Sharī'ah -compliant modes of investment, such as mushārakah, mudarabah, murabahah and istisna, among others (Abdullah and Ismail, 2015). Consequently, today, cash waqf is universally accepted provided that it is invested in a going concern Sharī'ah-compliant business. Therefore, as long as the business continues to exist, the profit on the invested cash would be used to carry out the intended waqf activities. Thus, assets like cash, shares, etc., could be used as waqf properties if all necessary measures are put in place to ensure their perpetual existence. According to Abdullah and Ismail (2015), ordinary shares of companies that have a perpetual existence could be used as waqf property provided that they have legal backing. The share waqf was practiced by Sulaiman bin Abdul Aziz Al Rajhi in 2013 when he endowed his $19.7 \%$ shareholdings in Al Rajhi Bank as waqf for religious and socio-economic development of the ummah.

Similarly, according to paragraph 8 of the financial reporting standard for waqf institutions (FAS No.37) developed by the AAOIFI, contribution to the waqf equity can be done in cash or in-kind. Briefly, contemporary waqf practices involve both cash and non-cash properties. In other words, the endowment could be either in cash or in-kind.

Concerning the initial recognition of the waqf asset, the standard (FAS No.37) provided the following: 
Umar \& Haron | Accounting for Waqf Institutions: Business, Not-for-Profit or Hybrid Entities?

- Waqf assets should be recognized at their fair values (paragraph 10)

- Waqf assets that are not expected to generate incomes (like mosques) should be recognized at their nominal values (paragraph 12)

Subsequently, the assets should be measured as follows:

- The waqf assets should be measured at their fair values and any gain or loss recognized directly in waqf equity, irrespective of the provisions of any AAOIFI's financial accounting standards. Hence, no depreciation or amortization should be charged on such assets (paragraph 14).

- The waqf assets that are not expected to generate incomes (like mosques) should be carried at their originally assigned values (paragraph 16).

Valuation of contribution in-kind corresponds with the earlier provisions of AAOFI's Musharakah Standard (FAS No.4). AAOIFI's Musharakah Standard (FAS No. 4) provides that:

The Islamic bank's share in musharakah capital provided in kind (trading assets or non-monetary assets for use in the venture) shall be measured at the fair value of the assets (the value agreed between the parties) [...] (para.5, p. 233).

Similarly, Bank Negara Malaysia $(2010 ; 2015)$ required that for a musharakah business to be valid, the contribution in-kind should be measured in monetary terms either based on an agreement between the partners or by a third party, such as experts, valuers or any other competent person, before the business is commenced. This signifies that any capital contribution to the partnership other than cash should be revalued at a market price or a price agreed between the partners. This is because the contribution in-kind can be in form of various assets, such as a motor van, furniture and fittings, land and buildings, livestock, machinery, etc., which all have money as a common unit of their measurements. Similarly, this principle of the revaluation of the contribution in-kind at the market price could be adapted by waqf institutions in the revaluation of the waqf assets. Therefore, as soon as a waqif (endower) donates his/her property for waqf, such an asset should be revalued at its market (or fair) value. The valuation of an asset at its market value is a common practice in Islam in a number of cases. For example, if a Muslim deceased left a business, its assets are required to be revalued at their current market prices and then total liabilities and legacies must be subtracted therefrom in order to arrive at the equity (or residue) to share among the heirs (Umar and Kurawa, 2019). 
Umar \& Haron | Accounting for Waqf Institutions: Business, Not-for-Profit or Hybrid Entities?

Briefly, in line with the literature, the contribution to waqf asset can be made in both cash and in-kind. If the asset is expected to provide economic benefits, it should be initially and subsequently measured at its fair value. However, if the waqf asset is not expected to provide economic benefits, like a mosque, it should be initially and subsequently measured at its nominal value.

\subsection{Waqf Institutions' Financial Statements}

\subsubsection{The Need for Accounting Information}

Accounting information is the processed transactions and events of an organization presented in its annual reports and accounts for decision making by various stakeholders that have either direct or indirect relationships with it. The stakeholders in an organization include customers, employees, local communities, suppliers and distributors and shareholders (Fontaine, Haarman and Schmid, 2006). The main source of information of any organization (whether profit, non-profit organization or government) is its annual reports and accounts (Kamaruddin and Ramlia, 2015).

The information needs of users of the annual reports and accounts increase and change with the increase in the categories of users (AAOIFI, 2015). This is because each user has a diversified reason for accessing the annual reports and accounts. For example, shareholders are primarily after the maximization of their wealth in a business, but credit suppliers look for the ability of the business to pay them as at when due. Similarly, in the case of waqf institutions accounting information is equally needed. In fact, in the view of Mansor et al. (2017), accountability in the waqf institutions is more demanding than in both private and public sectors, as the donors of waqf assets have no equity or personal stake in the institutions. This is because in general terms the diversity of the users of Islamic accounting information is more than that of its conventional counterpart (Yaacob et al., 2012).

The relationship between donors and managers can be explained by the agency theory, which is normally used to explain governance in the context of a principal-agent relationship in a profit-making entity (Abdullah and Ismail, 2015). Therefore the agency theory explains the relationship between a donor and a manager (Kamaruddin, Masruki and Hanefah, 2018). More clearly, since the waqf property is entrusted to a manager, conflict of interest may arise between the intentions of the donor and the interests of the trustee (Yaacob et al., 2012; Abdullah and Ismail, 2015). 
Umar \& Haron | Accounting for Waqf Institutions: Business, Not-for-Profit or Hybrid Entities?

Further, in consideration of the complexity of waqf institutions comprising various stakeholders, the stakeholder theory is found to be worthy applicable. it demands managers to manage the organization for the benefit of its stakeholders as well as act in such a way as to ensure the entity's survival so that the long-term stake of each group is safeguarded (Fontaine et al., 2006). The Stakeholder theory also supports the treatment of all stakeholders with fairness, honesty and even generosity (Harrison, Freeman and Sá de Abreu, 2015)

One of the ways by which waqf managers demonstrate fairness and honesty to all their stakeholders is to provide accounting information. Communicating true and fair view accounting information to users via annual reports and accounts could serve as a strong instrument for minimizing the conflict of interests not only between managers and endowers but also other stakeholders to the waqf institution. Hence, trustees are required to disclose adequate information related to the management of waqf funds (Kamaruddin et al., 2018). A good accounting report is expected to provide information that meets the expectations of its users (Masruki, Hussainey and Aly, 2016). Therefore, the accounting information prepared and communicated by the trustees to the users is expected to show their actions and inactions (Masruki et al., 2016).

The institution of waqf has many users for accounting information, such as waqif, beneficiaries, regulators and the community at large, among others (Ihsan and Adnan, n.d.; Ihsan and Hameed, 2011; Munuswamy and Mohamed, 2016). The endower (if alive) would make use of the accounting information to establish whether his/her intended objectives (as contained in the waqf deeds) are achieved. The waqif may continue to provide financial support to the institution (Mansor et al., 2017) if he/she is impressed by the way and manner waqf assets are managed and administered. In addition, the accounting information would be useful to potential donors, i.e., those who have intentions to have their foundations, particularly if the contributions of the waqf to the socio-economic development of the society are adequately disclosed in annual reports and accounts. The trustees themselves need the accounting information to measure their performance in terms of achieving waqf objectives efficiently and effectively. In a situation where deviations are found, managers would change their earlier plans and put in place appropriate control measures for better performance in the future. Beneficiaries of waqf assets also need accounting information. They can be the general public or an identified group of persons (say, a family) who must be clearly defined in the waqf deed (Osman, 2012). The beneficiaries would make use of the accounting information to evaluate whether the trustees provide goods or services to them as intended by the donor or provided in the waqf deeds. 
Umar \& Haron | Accounting for Waqf Institutions: Business, Not-for-Profit or Hybrid Entities?

Moreover, the government or relevant waqf regulatory agencies need accounting information. These agencies could make use of it to make policies as well as take necessary action (including punishment) where misappropriations or deviations from the intended objectives of the waqf are found. This is to improve waqf practices for the perpetual contribution to the socio-economic development of the Ummah.

Other stakeholders need waqf accounting information as obtainable in profitoriented entities, such as employees, customers, tax authorities and journalists, among others. This is because waqf institutions as an endowment entity also engage in commercial undertakings for their perpetual existence by transacting and having relationships with such stakeholders. These stakeholders to a business entity play vital roles to its survival and success (Freeman, 2004). This is because if they are well treated, they are likely to reciprocate with positive attitudes and behaviors to the entity (Harrison et al., 2015).

Briefly, in accordance with the authors' view, the users of waqf accounting information are complex than those of private (business) and the public sector since the waqf institutions have the features of both sectors. From the public sector perspective, it primarily aims at the socio-economic development of the Islamic society through the provisions of what is normally provided by the government, such as education, healthcare, water and other infrastructural facilities. On the other hand, the institutions are tied up to the private sector since they engage in businesses with a view to earning incomes for the sustainable welfare of beneficiaries. In conducting the business, the waqf institutions have relationships with suppliers, creditors, tax authorities and other private-sector regulatory agencies.

\subsubsection{The Preparation of the Financial Statements of Waqf Institutions}

The management of any organization (whether public or private) is mandated to prepare annual reports and accounts with the view to providing stewardship of the resources it is entrusted with. In specific, the preparation of annual reports and accounts by trustees of waqf institutions becomes necessary.

Normally, the preparation of financial statements is guided by accounting standards. Nowadays, most private entities across the globe adopt International Accounting Standards/ International Financial Reporting Standards (IAS/IFRS) in the preparation of their financial statements. On the other hand, the International Public Sector Accounting Standards (IPSASs) is the global accounting standards widely used for the preparation of 
Umar \& Haron | Accounting for Waqf Institutions: Business, Not-for-Profit or Hybrid Entities?

government accounting in the world. In addition, Islamic Financial Institutions (IFIs) are required to comply with AAOIFI's Standards as well as adapt the conventional standards (IAS/IFRS) in the preparation of their financial statements. As mentioned earlier, though waqf is a topical issue in Islamic Finance, there was no universal accounting standard to adopt by such an institution until 15 Rabi'll, 1442 A.H (equivalent to $30^{\text {th }}$ November, 2020) when the board of the AAOIFI approved the accounting standard for waqf institutions (FAS No. 37) for adoption with effect from the beginning of 2022.

Briefly, one could point out from the above that waqf institutions apply different accounting policies and practices, whereby some institutions are found to be more accountable than others. Discharging poor accountability functions in the past by some waqf institutions could be attributed to the lack of universal accounting standards to adopt by such institutions.

Besides, to prepare comprehensive annual reports and accounts, enhance the uniformity of accounting and reporting as well as minimize the incidences of the diversity of waqf accounting and reporting practices, scholars have different views. For example, some suggest the application of the accounting framework for business organizations while others recommend the adaption of the accounting frameworks of not-for-profit entities. Azmi and Hanifa (2015) studied two waqf organizations whose accounts are audited and published annually for public accessibility. These waqf institutions were found to have been applying accounting frameworks for profit-entities. The study also established that their financial reporting practices did not contravene the provisions of AAOIFI under Shari'ah Standard for Waqf No. 33 (SS 33). More so, Hamdan et al. (2013) argued that financial reporting practices for business entities are not suitable for adaption by mosques, as their nature resembles not-for-profit organizations.

However, FAS No. 37 (to be adopted from $1^{\text {st }}$ January, 2022) provides a comprehensive list of financial statements to prepare by Waqf institutions as follows:
a. statement of financial position as at the end of the period;
b. statement of financial activities for the period;
c. statement of Ghallah for the period;
d. statement of changes in waqf equity for the period;
e. statement of cash flows for the period; and
f. notes to the financial statements (paragraph 26).

From the above, it is understandable that the statement of Ghallah is uncommon among such statements. According to the standard (FAS No. 37), it is presented in a similar way to the statement of cash flows. It basically 
Umar \& Haron | Accounting for Waqf Institutions: Business, Not-for-Profit or Hybrid Entities?

reflects the real nature of the waqf institution by showing the extent to which the objectives of waqf are achieved for the welfare of the intended beneficiaries.

However, FAS No. 37 fails greatly to consider accounting issues for the commercial activities undertaken by waqf institutions in order to sustain their operations. These commercial activities are major sources of income to the waqf institutions. Hence, the need to account for their transactions is very profound. Normally, a not-for-profit entity is required to prepare the income statement when it engages in any business activity to earn a profit in order to provide additional income for carrying out the main purpose of the organization (Wood and Sangster, 2012). For example, the association, in addition to its core activities, maintains a bar/restaurant where food, snacks and drinks are sold to members and other people (Institute of Chartered Accountants of Nigeria, 2009). Hence, income statements must at least be prepared for the commercial activities of waqf institutions.

Briefly, waqf institutions operate like charitable organizations and undertake commercial activities concurrently. In addition to the financial statements for their waqf activities they are expected to show at least show income statements for their commercial activities, Though the annual reports and accounts of the waqf institutions may be voluminous, it would be better if income statement, statement of financial position, statement of changes in equity and statement of cash flows for the commercial activities of the institutions are integrated into their annual reports and accounts, being hybrid entities. This is more practicable in the case of Small and medium-sized waqf institutions.

\section{v. Conclusion and Recommendations}

\subsection{Conclusion}

Accounting is one of the essential aspects of the institutions which plays a significant role not only in its sustainability but also ensures it is intended objectives are achieved efficiently and effectively. For a long-time, lack of universal waqf accounting standards also bring about variations in financial accounting and reporting practices of waqf institutions not only across the globe but in the same countries, like Malaysia. This greatly contributed to the poor accountability of waqf institutions which leads to underperformance and even the collapse of some of them. However, on 15 Rabi'll, 1442 A.H (equivalent to $30^{\text {th }}$ November, 2020) the board of the AAOIFI approved the accounting standard for waqf institutions (FAS No. 37) for adoption effective 
Umar \& Haron | Accounting for Waqf Institutions: Business, Not-for-Profit or Hybrid Entities?

from 01 January, 2022. Hence, the objective of this study is to establish whether waqf institutions should be classified as nonprofit, private or hybrid entities with the view to providing the contents of their annual reports and accounts. Analysis of the waqf institutions showed that they are hybrid entities even though they are primarily established for religious and socioeconomic development purposes, commercial undertakings are mostly attached to them so that they continue to exist perpetually. Therefore, they are expected to prepare and report both waqf and commercial activities in the annual reports and accounts. However, AAOIFI's FAS No.37 which is believed to be the first universal accounting standard for waqf institutions largely focused on accounting and reporting issues for charitable activities. In other words, pays little or no attention to commercial activities undertaken by waqf institutions.

\subsection{Recommendations}

Based on the findings of the study, the study provides three key recommendations. First, there is a need to develop regulations, guidelines and more importantly a waqf accounting standard that will oblige or motivate waqf institutions to adequately disclose both waqf and commercial activities in their annual reports and accounts. Second, AAOIFI should consider the possibility of including commercial undertakings in the next amendment of the standard (FAS No. 37). Third, there is a need to create awareness and knowledge of financial accounting and reporting on the sustainability of waqf institutions among potential and actual donors. This could be achieved through collaborations among relevant government agencies, professionals and academics.

\section{Acknowledgment}

This is to acknowledge that this paper was presented at the conference jointly organized by the International Center for Education in Islamic Finance (INCEIF) and the International Shariáh Academy for Islamic Finance (ISRA), Malaysia, held between $25^{\text {th }}-26^{\text {th }}$ November, 2019 at the Intercontinental Hotel, Kuala Lumpur, Malaysia. 
Umar \& Haron | Accounting for Waqf Institutions: Business, Not-for-Profit or Hybrid Entities?

\section{References}

Abdullah, R., \& Ismail, A.G. (2015). Taking stock on the waqf-based Islamic microfinance model. International Journal of Social Economics, 44(8), 1018-1031.

Accounting and Auditing Organization for Islamic Financial Institutions (2015). Financial Reporting by Waqf Institutions. Retrieved April 30, 2021, from http://aaoifi.com/fas-37-financial-reporting-by-waqfinstitutions-2/?lang=en.

Ahmed, J. (2010). Documentary research method: new dimensions. Indus Journal of Management and Social Science, 4, 1-14.

Azmi, A. C., \& Hanifa, M.H. (2015). The Sharia-compliance of financial reporting practices: a case study on waqf. Journal of Islamic Accounting and Business Research, 6 (1), 55 - 72. http://dx.doi.org/10.1108/JIABR-10-2012-0069.

Bank Negara Malaysia (2015). Musyrakah. Bank Negara Malaysia, Kuala Lumpur.

Bank Negara Malaysia (2010). Draft of shariah parameter reference 4: Musharakah contract. Bank Negara Malaysia, Kuala Lumpur.

Bowen, G. (2009). Document analysis as a qualitative research method. Qualitative Research Journal, 9 (2), 27-40, https://doi.org/10.3316/QRJ0902027

Fontaine, C., Haarman, A., \& Schmid, S. (2006). The stakeholder theory. Retrieved September 9, 2019, from ttps://www.semanticscholar.org/paper/The-Stakeholder-TheoryFontaine-Haarman/fd7526ad023f2337cc01a123ead2d60191d1620c

Freeman, R.E. (2004). A stakeholder theory of the modern corporation. In T. L. Beauchamp \& M. E. Bowie (Eds.), Ethical theory and business (7th ed., pp. 55-64). Upper Saddle River, NJ: Pearson/Prentice Hall.

Habidin, N.F., Hussin, M.Y.M., Muhammad, F., Janudin, S.E., \& Fuzi, N.M. (2017). Critical success factors, benefit, and auditing of waqf accounting. International Journal of Academic Research in Business and Social Sciences, 7(4), 1184- 1189. https://doi.org/10.6007/IJARBSS/v7-i4/2925.

Hamdan, N., Ramli, A.M., Jalil, A., \& Haris, A. (2013). Accounting for waqf institutions: a review on the adaptation of fund accounting in developing the Shariah-compliant financial reports for mosque. Paper presented at World Universities' Islamic Philanthropy Conference 2013 (WIPCON 2013), Organized by IKAZ and UITM, 4 \& 5 December. 
Umar \& Haron | Accounting for Waqf Institutions: Business, Not-for-Profit or Hybrid Entities?

Harrison, J.S., Freeman, R.E., \& Sá de Abreu, M.C. (2015). Theory as an ethical approach to effective management: applying the theory to multiple contexts. Review of Business Management, 17 (55), 858-869.

Ibrahim, D.B., \& Ibrahim, H.B. (n.d.). Revitalization of Islamic trust institutions through corporate waqf. Retrieved July 10, 2019, from https://www.academia.edu/9186209/Revitalization_of_Islamic_Trus t_Institutions_through_Corporate_Waqf.

Ihsan, H. and Adnan, M.A. (n.d.). Waqf accounting and the construction of accountability. Retrieved August 10, 2019, from https://www.academia.edu/504496/Waqf_Accounting_and_The_Co nstruction_of_Accountability.

Ihsan, H., \& Hameed, S.M.I. (2011). Waqf accounting, and management in Indonesian waqf institutions: the cases of two waqf foundations. Humanomics, $27 \quad$ (4), 252-269. https://doi.org/10.1108/08288661111181305.

Ihsan, H., Sulaiman, M., Alwi, N.M., \& Adnan, M.A. (2017). A study of accountability practice in Dompet Dhuafa Waqf of Indonesia. Journal of King Abdulaziz University: Islamic Economics, 30 (2), 13-32.

Institute of Chartered Accountants of Nigeria (2009). Fundamental Financial Accounting. Lagos: VI Publishers.

Kahf, M. (2003). The role of waqf in improving the ummah welfare. Paper presented to the International Seminar on "Waqf as a private lega I body" Organized by Islamic University of North Sumatra, Medan, Indonesia, January 6-7. Retreived August 30, 2019 from monzer.kahf.com, papers, english, ROLE_OF_WAQF_IN_THE_WELF.

Kahf, M. (2012). Challenges and opportunities in harnessing waqf for the provision of social services. Retrieved May 18, 2018, from monzer.kahf.com/papers/english/WAQF_and_its_Sociopolitical_Asp ects.pdf.

Kahf, M. (n.d). Waqf and its sociopolitical aspects. Retrieved May 18 from monzer.kahf.com/papers/english/WAQF_and_its_Sociopolitical_Asp ects.pdf.

Kamaruddin, M.I.H., \& Ramlia, N.M. (2015). Enhancing financial accountability of Islamic philanthropic organizations through financial disclosure. Online Journal of Research in Islamic Studies, 2 (1), 29-42.

Kamaruddin, M. I. H., Masruki, R., \& Hanefah, M. M. (2018). Financial and non-financial disclosure practices in selected awqaf institutions. International Journal of Nusantara Islam, 06 (01), 52- 73, https://doi.org/10.15575/ijni.v6i1.1929 
Umar \& Haron | Accounting for Waqf Institutions: Business, Not-for-Profit or Hybrid Entities?

Kuran, T. (2001). The Provision of public goods under Islamic law: origins, impact and limitations of the waqf System", Law \& Society Review, 35 (4), 841-898. http://www.jstor.org/stable/3185418.

Mahata, M. A., Jaaffara, M. Y., \& Abdul Rasoola, M. S. (2015). Potential of micro-waqf as an inclusive strategy for development of a nation. Procedia Economics and Finance, 31, 294 - 302. https://doi.org/10.1016/S2212-5671(15)01193-4

Mansor, N., Jamil, A., \& Bahari, A. (2017). Integrated waqf reporting system. International Journal of Accounting, Finance and Business (IJAFB), 2 (6), 155 - 166.

Masruki, R., \& Shafii, Z. (2013). The development of waqfaccounting in enhancing accountability. Middle-East Journal of Scientific Research, 1-6. DOI: httpps://doi.org/10.5829/idosi.mejsr.2013.13.1873.

Masruki, R., Hussainey, K., \& Aly, D. (2016). Expectations of stakeholders on the information disclosure from the Malaysian State Islamic Religious Councils (SIRCs) Reporting. Global Review of Accounting and Finance, $7(2), 112-128$.

Miran, J. (2009). Endowing property and edifying power in a Red Sea Port: waqf, Arab Migrant entrepreneurs, and urban authority in Massawa, 1860s-1880s. International Journal of African Historical Studies, 42 (2), 151- 178 .

Munuswamy, S., \& Mohamed, Z. (2016). Financial disclosure pattern of State Waqf Boards in India: an exploratory study. Journal of Islamic Economics, Banking and Finance, 12 (4), 138-154.

Osman, A. Z. (2012). Accountability in managing waqf properties: the case of two State Religious Councils in Malaysia. Thesis submitted to the University of London for the degree of Doctor of Philosophy School of Management, Royal Holloway University of London. Retrieved August 18, 2019 from https://ethos.bl.uk/OrderDetails.do?uin=uk.bl.ethos.553846.

Rusydiana, A. S., \& Devi, A. (2018). Elaborating cash waqf development in Indonesia using analytic network process. International Journal of Islamic Business and Economics, 2 (1), 1-13.

Sait, S. and Lim, H. (2006). Land, Law and Islam: Property and human rights in the Muslim world. London : Zed Books Ltd.

Salarzehi, H., Armesh, H., \& Nikbin, D. (2010). Waqf as a Social Enterpreneurship Model in Islam. International Journal of Business and Management, 5 (7), 179-186.

Scott, J. (1990). A Matter of Record: Documentary Sources in Social Research. Cambridge: Polity Press. 
Umar \& Haron | Accounting for Waqf Institutions: Business, Not-for-Profit or Hybrid Entities?

Shulthoni, M., \& Saad, N. M. (2018). Waqf fundraising management: a conceptual comparison between traditional and modern methods in the Waqfinstitutions. Indonesian Journal of Islam and Muslim Societies, 8 (1), 57-86. https://doi.org/10.18326/ijims.v8i1.57-86

Talib, N. Y. A., Latiff, R. A., \& Aman, A. (2020). An institutional perspective for research in waqf accounting and reporting: A case study of Terengganu state Islamic Religious Council in Malaysia. Journal of Islamic Accounting and Business Research, 11 (2), 400427. https://doi.org/10.1108/JIABR-11-2016-0132.

Talib, N. Y. A., Latiff, R. A., Aman, A., \& Palil, M. R. (2018). An exploratory study of accounting and reporting practice for Waqf among State Islamic Religious Councils in Malaysia. International Journal of Islamic Thought, 13, 90- 105.

Umar, U. H. (2021). Adapting the Al Rajhi waqf model to mitigate the impact of COVID-19 on the ummah, in M. K. Hassan, A. Muneeza, \& A.M. Sarea (Eds.), COVID-19 and Islamic Social Finance. London: Routledge. https://doi.org/10.4324/9781003121718.

Umar, U. H. (2019). Integrating family waqf into an inheritable going concern business: an instrument for the sustainable welfare of exempted heirs, Ali,K.M., M.K. Hassan, and A.E.S. Ali (Eds.) Revitalization of Waqf for Socio-Economic Development (pp. 87-87) Volume II. Cham: Springer. https://doi.org/10.1007/978-3-030-18449-0_4.

Umar, U. H., \& Kurawa, J. M. (2019). Business succession from Islamic an accounting perspective", ISRA International Journal of Islamic Finance, 11 (2), 267-281. https://doi.org/10.1108/IJIF-06-2018-0059

Umar, U. H., Abu Bakar, M., Baita, A. J., Kademi, T. T., \& Haron, M.H. (2021). Do academic and professional institutions promote the awareness and knowledge of Islamic banking and finance in Nigeria?. Journal of Islamic Accounting and Business Research. https://doi.org/10.1108/JIABR-05-2020-0171

Wood, F., \& Sangster, A. (2012). Frank's Wood Business Accounting 1, 12 (eds.). Essex: Pearson Education Limited.

Yaacob, H., \& Nahar, H.S.(2017). Investigating awqaf management, accounting and investment practices in Malaysia: the case of a State Religious Institution. Global Journal of Al-Thaqafah, 7 (1), 59-70.

Yaacob, H., Petra, S., Sumardi, W., \& Nahar, H. S. (2012). Awqaf accounting and reporting for accountability: a case study of Awqaf S. Proceedings of 19th International Business Research Conference. Available at: SSRN: https://ssrn.com/abstract=2175459 or http://dx.doi.org/10.2139/ssrn.2175459 . 
Umar \& Haron | Accounting for Waqf Institutions: Business, Not-for-Profit or Hybrid Entities?

Yaacob, H., Petra, S., Sumardi, A., \& Nahar, H. S. (2015). Accountability through accounting and reporting lenses. Humanomics, 31(3), $299-$ 313. http://dx.doi.org/10.1108/H-07-2013-0049.

Yalawae, A., \& Tahir, I. M., (2008). The Role of Islamic institution in achieving equality and human development : waqf or edowment. Paper presented at the 5th annual conference of the HDCA, 10-13 September 2008, New Dehli, India. Retreived August 10, 2019, from https://hd-ca.org/publications/.

Yusof, N. (2021). Specific Accounting Standards for Waqf Institutions. Journal of Emerging Economies and Islamic Research, 9(1), 29-42.

Zarqa, M. A.(1994). Financing and investment of awqaf projects: a nontechnical introduction. Islamic Economic Studies, 1, 55-62. 